\title{
Effects of oscillating dietary crude protein concentrations on production, nutrient digestion, plasma metabolites, and body composition in lactating dairy cows
}

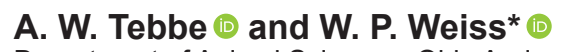

Department of Animal Sciences, Ohio Agricultural Research and Development Center, The Ohio State University, Wooster 44691

\begin{abstract}
We hypothesized that dairy cows fed oscillating metabolizable protein (MP) and crude protein (CP) concentrations on a 24-h frequency for a diet formulated to be below MP requirements would use $\mathrm{N}$ more efficiently (i.e., increased milk protein yields and less manure $\mathrm{N}$ ) without increasing mobilization of body protein stores than would cows fed the same deficient MP diet continuously, although both treatments would on average have equal MP concentrations. In a randomized block design, 30 Holstein cows $(119 \pm 21 \mathrm{~d}$ in milk; $667 \pm$ $69 \mathrm{~kg}$ of body weight) were blocked according to milk yield within a parity ( 3 primiparous and 7 multiparous blocks) and fed 1 of 3 treatments: (1) diet with $16.2 \% \mathrm{CP}$ (109\% of MP requirements) fed continuously (109MP), (2) diet with $14.1 \%$ CP (95\% of MP requirements) fed continuously (95MP), or (3) diets oscillating on a $24-\mathrm{h}$ cycle from the 109MP diet and a diet with $11.9 \% \mathrm{CP}$ ( $\sim 78 \%$ of MP requirements) such that average $\mathrm{CP}$ and MP concentration would be the same as $95 \mathrm{MP}$ (OSC). Dry matter intake was similar between 109MP and $95 \mathrm{MP}$ (22.9 vs. $23.2 \mathrm{~kg} / \mathrm{d}$ ) but tended to be lower for OSC $(22.2 \mathrm{~kg} / \mathrm{d})$ compared with $95 \mathrm{MP}$. Milk yield was greater for 109MP compared with 95MP (36.6 vs. 35.1 $\mathrm{kg} / \mathrm{d})$ and similar between $95 \mathrm{MP}$ and OSC $(35.3 \mathrm{~kg} / \mathrm{d})$. Milk protein and energy-corrected milk yields were similar among treatments. Milk urea N (MUN) concentration was higher for 109MP compared with 95MP (12.8 vs. $10.2 \mathrm{mg} / \mathrm{dL})$, and tended to be higher for OSC (10.9 $\mathrm{mg} / \mathrm{dL}$ ) compared with 95MP. Higher MUN concentration for OSC occurred despite lower $\mathrm{N}$ intake (474 vs. $512 \mathrm{~g}$ of $\mathrm{N} / \mathrm{d}$ ) and similar milk $\mathrm{N}$ outputs compared with 95MP (164 vs. $179 \mathrm{~g} / \mathrm{d}$ ). On days when cows on OSC were fed high versus low MP diets, yields of milk ( 34.8 vs. $36.3 \mathrm{~kg} / \mathrm{d})$ and milk protein (1.0 vs. $1.1 \mathrm{~kg} / \mathrm{d}$ ) and MUN concentration (9.3 vs. $12.5 \mathrm{mg} / \mathrm{dL}$ ) followed the oscillation pattern but lagged the change in diet
\end{abstract}

Received March 29, 2020.

Accepted June 21, 2020.

*Corresponding author: weiss.6@osu.edu
CP by $1 \mathrm{~d}$, whereas dry matter intake, yields of milk fat, plasma energy metabolites, AA, and 3-methyl-His were similar between days. Nutrient digestibility was similar for major nutrients across treatments except for $\mathrm{CP}$, which was greater for 109MP (65.2\%) and OSC (65.3\%) compared with 95MP $(61.7 \%)$. Compared with $95 \mathrm{MP}$, OSC did not increase milk $\mathrm{N}$ relative to $\mathrm{N}$ intake (averaged $0.35 \mathrm{~g}$ of milk $\mathrm{N} / \mathrm{g}$ of $\mathrm{N}$ intake) or $\mathrm{N}$ balance; however, urinary $\mathrm{N}$ output was increased for OSC versus $95 \mathrm{MP}$ (0.32 vs. $0.24 \mathrm{~g}$ of urine $\mathrm{N} / \mathrm{g}$ of $\mathrm{N}$ intake). Body composition estimated using urea dilution was similar across treatments, and all cows accreted lipid and energy during the trial. Empty body CP did not change over the 50-d treatment period. Overall, greater $\mathrm{CP}$ digestion, urinary $\mathrm{N}$ excretion, and MUN concentrations with lesser $\mathrm{N}$ intake and similar milk $\mathrm{N}$ outputs for OSC compared with 95MP suggests that the lower energy intake by OSC cows may have limited potential responses to altered $\mathrm{N}$ metabolism.

Key words: nitrogen metabolism, amino acids, body composition, manure nitrogen

\section{INTRODUCTION}

Moderately decreasing dietary CP (e.g., 16 to $14 \%$ $\mathrm{CP})$ consistently improves nitrogen utilization efficiency (NUE; milk $\mathrm{N} / \mathrm{N}$ intake) by dairy cows and can reduce feed cost but is rarely done on farms because lower $\mathrm{CP}$ concentrations often decrease milk and milk protein yields (Jonker et al., 2002; Huhtanen and Hristov, 2009). Reduced milk production when dietary $\mathrm{CP}$ is decreased can outweigh environmental gains from reduced manure $\mathrm{N}$ excretion at the individual farm level because globally more cows would be needed to produce the same quantity of milk (VandeHaar and StPierre, 2006).

Oscillating dietary CP concentrations from deficient to adequate levels may improve NUE and allow diets with lower average $\mathrm{CP}$ concentrations to be fed without reducing milk production. In growing wethers and steers, oscillating dietary CP concentrations (i.e., 10 to $15 \% \mathrm{CP}$ ) every $48 \mathrm{~h}$ improved NUE and maintained BW 
gain compared with animals continuously fed a higher average CP concentration (Cole, 1999; Archibeque et al., 2007a). Improved NUE when oscillating CP may be from less urinary $\mathrm{N}$ excretion and more $\mathrm{N}$ recycled to the rumen for microbial protein synthesis, which increases MP supply compared with continuously feeding a similar average CP concentration (Archibeque et al., 2007b; Doranalli et al., 2011).

Previously, our laboratory found oscillating CP every $48 \mathrm{~h}$ from 10.3 and $16.4 \%$ in dairy cows numerically decreased milk and milk protein yields compared with continuously feeding a 13.4\% CP diet (Brown, 2014). However, results from Brown (2014) and a preliminary experiment we conducted suggested feeding a deficient $\mathrm{CP}$ concentration for $48 \mathrm{~h}$ may be too long, and the average MP concentration of the oscillation treatment was too deficient for maintaining milk production. Because manure $\mathrm{N}$ excretion and body composition were not measured in those studies, we do not know whether oscillating $\mathrm{CP}$ in dairy cows can improve NUE and whether improved NUE is caused by reducing manure $\mathrm{N}$ excretion or increased mobilization of body protein.

Our objective was to determine whether oscillating dietary $\mathrm{CP}$ and MP every $24 \mathrm{~h}$ would alter milk production, nutrient digestion, plasma metabolites, and body composition in lactating dairy cows. We hypothesized that oscillating the MP concentrations on a 24-h frequency for a diet that was formulated to be below MP requirements would improve NUE, increase milk and milk protein yields, and reduce manure $\mathrm{N}$ excretion without increasing mobilization of body protein stores compared with feeding a diet with a similar average MP concentration continuously.

\section{MATERIALS AND METHODS}

\section{Cows and Treatments}

All procedures involving animals were approved by The Ohio State University Institutional Animal Care and Use Committee (protocol \#2018A00000040). Nine primiparous and 21 multiparous cows $(119 \pm 21$ DIM at the start of the experiment) were used in a randomized block experiment. Cows were blocked according to parity and 10-d average milk yield (primiparous blocks: $34 \pm 2.3 \mathrm{~kg} / \mathrm{d}, 637 \pm 43 \mathrm{~kg}$ of BW; multiparous blocks: $41 \pm 4.0 \mathrm{~kg} / \mathrm{d}, 683 \pm 74 \mathrm{~kg}$ of BW). Limited available stalls required the trial to be conducted in 2 groups of 15 cows. Treatments were represented equally in each group. The experiment consisted of a 10-d covariate period and $50 \mathrm{~d}$ of treatment feeding for each group (group 1: May to July 2018; group 2: August to October 2018). Treatments (Tables 1 and 2) were (1) a diet that on average provided $109 \%$ of MP requirements (NRC,
Table 1. Ingredient composition of $\operatorname{diets}^{1}$

\begin{tabular}{|c|c|c|c|}
\hline \multirow[b]{2}{*}{ Ingredient, $\%$ of $\mathrm{DM}$} & \multicolumn{3}{|c|}{ Treatment $\operatorname{diet}^{2}$} \\
\hline & $\begin{array}{l}\text { High phase } \\
\text { OSC }\end{array}$ & $95 \mathrm{MP}$ & $\begin{array}{c}\text { Low phase } \\
\text { OSC }\end{array}$ \\
\hline Corn silage & 40.5 & 40.5 & 40.5 \\
\hline Alfalfa silage & 14.0 & 14.0 & 14.0 \\
\hline Corn grain & 19.5 & 21.7 & 23.9 \\
\hline Soybean meal, $48 \% \mathrm{CP}$ & 16.1 & 11.1 & 6.1 \\
\hline Soy hulls & 6.6 & 9.1 & 11.7 \\
\hline Animal/vegetable fat & 0.51 & 0.51 & 0.51 \\
\hline Calcium soaps of $\mathrm{FA}^{3}$ & 0.86 & 0.86 & 0.86 \\
\hline Limestone & 0.23 & 0.12 & - \\
\hline Dicalcium phosphate & 0.41 & 0.55 & 0.68 \\
\hline Dynamate $e^{4}$ & 0.11 & 0.15 & 0.19 \\
\hline Potassium carbonate $^{5}$ & - & 0.12 & 0.23 \\
\hline Minerals/vitamins ${ }^{6}$ & 1.4 & 1.4 & 1.4 \\
\hline
\end{tabular}

${ }^{1}$ The average ingredient composition fed to the 2 groups of cows used in the experiment ( $\mathrm{n}=15$ cows per group).

${ }^{2}$ Treatments were (1) providing $109 \%$ of MP requirements continuously (109MP), (2) providing 95\% of MP requirements fed continuously (95MP), or (3) 24-h oscillations from 109MP and a diet providing $78 \%$ of MP requirements (OSC). The 109MP treatment was fed the high phase OSC diet continuously. The 95MP treatment is the average of the high and low phase of OSC diets and fed continuously. The OSC treatment oscillated from the high phase OSC diet to low phase OSC diet on a 24 -h basis.

${ }^{3}$ Megalac, Church \& Dwight Co. Inc., Piscataway, NJ. FA = fatty acids.

${ }^{4}$ Mosaic Co., Plymouth, MN.

${ }^{5}$ DCAD Plus, Church \& Dwight Co. Inc..

${ }^{6}$ Premix contained $49.0 \%$ trace mineral salt (Morton Salt Inc., Chicago, IL), $7.1 \%$ magnesium oxide (Animag Prilled 30/100, Martin Marietta Magnesia Specialties LLC, Baltimore, MD), $11.9 \%$ sodium selenate premix (200 mg Se $/ \mathrm{kg}$ ), 0.25\% copper sulfate, $0.28 \%$ Zinpro $120(120 \mathrm{~g}$ $\mathrm{Zn} / \mathrm{kg}$, Zinpro Corp., Eden Prairie, MN), 0.7\% vitamin A (30 kIU/g), $2.2 \%$ vitamin D (3 $\mathrm{kIU} / \mathrm{g})$, and $3.3 \%$ vitamin $\mathrm{E}(44 \mathrm{kIU} / \mathrm{kg}), 24.7 \%$ biotin premix $(220 \mathrm{mg} / \mathrm{kg}$ ), and $0.48 \%$ Rumensin-90 (Elanco Animal Health, Greenfield, IN).

2001) fed continuously (109MP), (2) a diet that on average provided $95 \%$ of MP requirement fed continuously (95MP), or (3) 24-h oscillations from the 109MP diet and a diet that provided $78 \%$ of MP requirements (OSC). The CP and MP concentrations of OSC were on average equal to 95MP. For the covariate period, all cows were continuously fed the $109 \mathrm{MP}$ diet. Cows were housed in individual tiestalls and were fed once daily $(0700 \mathrm{~h})$ as a TMR with a refusal rate of 3 to $5 \%$.

For each group, 2 diets were formulated to administer treatments: a high and a low phase OSC diet (Tables 1 and 2). The high phase OSC diet was also the 109MP treatment diet and formulated to meet $105 \%$ of the NRC (2001) MP requirement (actual was 109\%) for cows at the start of the experiment. The low phase of OSC diet provided about $80 \%$ of the MP requirement (actual was 78\%) and reduced milk yields $3.2 \pm 0.98$ $\mathrm{kg} / \mathrm{d}$ based on a preliminary experiment. The $95 \mathrm{MP}$ treatment diet was a 50:50 mix of the high and low phase OSC diets and met $95 \%$ of MP requirements. 
Table 2. Nutrient composition of $\operatorname{diets}^{1}$

\begin{tabular}{|c|c|c|c|}
\hline \multirow[b]{2}{*}{ Nutrient $^{3}$} & \multicolumn{3}{|c|}{$\operatorname{Diet}^{2}$} \\
\hline & $\begin{array}{l}\text { High phase } \\
\text { OSC }\end{array}$ & $95 \mathrm{MP}$ & $\begin{array}{c}\text { Low phase } \\
\text { OSC }\end{array}$ \\
\hline$\overline{\mathrm{DM}}, \%$ & 60.0 & 59.2 & 58.8 \\
\hline $\mathrm{OM}, \%$ of $\mathrm{DM}$ & 93.5 & 93.5 & 93.6 \\
\hline $\mathrm{CP}, 4 \%$ of DM & 16.2 & 14.1 & 11.9 \\
\hline $\mathrm{RDP}^{5} \%$ of DM & 10.4 & 9.1 & 7.8 \\
\hline $\mathrm{MP}^{5} \%$ of DM & 11.6 & 10.1 & 8.7 \\
\hline RUP, $\%$ of DM & 5.4 & 4.8 & 4.2 \\
\hline Forage NDF, $\%$ of DM & 22.4 & 22.4 & 22.4 \\
\hline $\mathrm{NDF}, \%$ of DM & 31.3 & 33.1 & 35.0 \\
\hline $\mathrm{NDF}_{\text {om }+\mathrm{cp}}, \%$ of DM & 29.7 & 31.4 & 33.1 \\
\hline NDICP, $\%$ of DM & 1.06 & 1.16 & 1.26 \\
\hline Starch, $\%$ of DM & 26.0 & 27.6 & 29.1 \\
\hline LCFA, \% of DM & 3.51 & 3.48 & 3.45 \\
\hline ROM, $\%$ of DM & 16.5 & 15.3 & 14.2 \\
\hline $\mathrm{ROM}_{\mathrm{om}+\mathrm{cp}}, 6$ of DM & 18.1 & 17.1 & 16.0 \\
\hline $\mathrm{NE}_{\mathrm{L}}{ }^{5} \mathrm{Mcal} / \mathrm{kg}$ & 1.63 & 1.61 & 1.59 \\
\hline $\mathrm{Ca}, \%$ of DM & 0.88 & 0.86 & 0.85 \\
\hline $\mathrm{P}, \%$ of $\mathrm{DM}$ & 0.39 & 0.40 & 0.41 \\
\hline $\mathrm{Mg}, \%$ of $\mathrm{DM}$ & 0.26 & 0.25 & 0.24 \\
\hline $\mathrm{K}, \%$ of $\mathrm{DM}$ & 1.34 & 1.33 & 1.32 \\
\hline $\mathrm{Na}, \%$ of $\mathrm{DM}$ & 0.32 & 0.31 & 0.30 \\
\hline $\mathrm{S}, \%$ of $\mathrm{DM}$ & 0.22 & 0.22 & 0.21 \\
\hline $\mathrm{Cu}, \mathrm{mg} / \mathrm{kg}$ & 16 & 15 & 14 \\
\hline $\mathrm{Fe}, \mathrm{mg} / \mathrm{kg}$ & 249 & 271 & 292 \\
\hline $\mathrm{Mn}, \mathrm{mg} / \mathrm{kg}$ & 66 & 64 & 62 \\
\hline $\mathrm{Zn}, \mathrm{mg} / \mathrm{kg}$ & 78 & 76 & 74 \\
\hline
\end{tabular}

${ }^{1}$ The average ingredient composition fed to the 2 groups of cows used in the experiment ( $\mathrm{n}=15$ cows per group).

${ }^{2}$ Treatments were (1) providing $109 \%$ of MP requirements continuously (109MP), (2) providing 95\% of MP requirements fed continuously (95MP), or (3) 24-h oscillations from 109MP and a diet providing $78 \%$ of MP requirements (OSC). The 109MP treatment was fed the high phase OSC diet continuously. The 95MP treatment is the average of the high and low phase of OSC diets and fed continuously. The OSC treatment oscillated from the high phase OSC diet and low phase OSC diet on a 24-h basis.

${ }^{3} \mathrm{LCFA}=$ long-chain fatty acids; residual organic matter $(\mathrm{ROM})=$ $100-\% \mathrm{CP}-\% \mathrm{LCFA}-\%$ ash $-\%$ starch $-\% \mathrm{NDF}$.

${ }^{4}$ The SD of diet CP concentrations across week of treatment feeding was $0.71,0.57$, and 0.44 for the high phase of OSC, $95 \mathrm{MP}$, and low phase of OSC diets, respectively. The SD was determined using the SD of ingredients and 100 permutations of a Monte Carlo simulation to estimate variance.

${ }^{5}$ Estimated using the NRC (2001) model with average DMI.

${ }^{6} \mathrm{NDF}_{\mathrm{om}+\mathrm{cp}}=\mathrm{NDF}-\mathrm{NDI}$-ash (ashed NDF residues) - NDICP (NDF residues analyzed for $\mathrm{CP}$ ); $\mathrm{ROM}_{\mathrm{om}+\mathrm{cp}}=100-\% \mathrm{CP}-\% \mathrm{LCFA}-\%$ ash $-\%$ starch $-\% \mathrm{NDF}_{\mathrm{om}+\mathrm{cp}}$.

The low phase OSC diet was made by replacing soybean meal in the high phase OSC diet with corn grain and soyhulls and balancing for minerals. We replaced both soyhulls and corn grain to reduce potential negative effects of high starch concentrations on milk fat synthesis. The composition of the alfalfa silage differed between groups (Table 3); therefore, ingredient composition of diets had to be altered slightly so that nutrient composition was the same across groups (Supplemental Tables S1 and S2; https://doi.org/10.3168/jds.2020 -18613).

\section{Measurements, Sampling, and Laboratory Analyses}

For each cow, feed ingredient delivery and refusal amounts were weighed and recorded daily. Silages were sampled weekly, analyzed for $\mathrm{DM}\left(100^{\circ} \mathrm{C}\right.$ for 48 $\mathrm{h}$ ), and used to adjust diets for any changes in silage DM. Concentrates and silages were sampled twice per week and composited monthly (2 composite samples per group) for nutrient analyses. Refusal samples were taken once during the covariate period and every $2 \mathrm{wk}$ during treatment feeding, analyzed for $\mathrm{DM}\left(100^{\circ} \mathrm{C}\right.$ for $48 \mathrm{~h}$ ), and used to calculate DMI. Cows were milked twice daily at 0400 and $1600 \mathrm{~h}$, and milk yields were measured electronically (Afimilk, Kibbutz Afikim, Israel). Milk samples were collected weekly from 4 consecutive milkings for analysis of milk fat, true protein, and lactose (B2000 Infrared Analyzer, Bentley Instruments, Chaska, MN), and MUN concentration (Skalar SAN Plus segmented flow analyzer, Skalar Inc., Norcross, GA) by DHI Cooperative Inc. (Columbus, OH). The weighted average of a.m. and p.m. samples based on milk yield at sampling was used to calculate milk component yield for each day. Milk component yields measured on consecutive days were taken to capture each phase of oscillation (i.e., high and low).

On d 10 of the covariate period and on consecutive mornings during the middle (group 1: d 24 and 25; group 2: d 27 and 28) and end of treatment feeding (d 49 and 50), blood was collected approximately 1

Table 3. Nutrient composition of forages included in the $\operatorname{diets}^{1}$

\begin{tabular}{|c|c|c|c|}
\hline \multirow[b]{2}{*}{ Nutrient $^{2}$} & \multirow{2}{*}{$\begin{array}{l}\text { Corn } \\
\text { silage }\end{array}$} & \multicolumn{2}{|c|}{ Alfalfa silage } \\
\hline & & Group 1 & Group 2 \\
\hline $\mathrm{DM}, \%$ & 31.9 & 38.5 & 37.6 \\
\hline $\mathrm{OM}, \%$ of $\mathrm{DM}$ & 96.1 & 89.3 & 91.2 \\
\hline $\mathrm{CP}^{3} \%$ of $\mathrm{DM}$ & 7.30 & 22.8 & 17.6 \\
\hline $\mathrm{NDF}, \%$ of $\mathrm{DM}$ & 41.7 & 33.0 & 51.0 \\
\hline $\mathrm{NDF}{ }^{4} \%$ of DM & 40.4 & 30.7 & 48.4 \\
\hline NDICP, \% of DM & 0.74 & 1.56 & 1.80 \\
\hline Starch, $\%$ of DM & 29.3 & 3.00 & 2.01 \\
\hline LCFA, $\%$ of DM & 2.66 & 3.00 & 2.01 \\
\hline $\mathrm{ROM}, \%$ of $\mathrm{DM}$ & 15.1 & 29.0 & 18.3 \\
\hline $\mathrm{ROM}_{\mathrm{om}+\mathrm{cp}}, \%$ of DM & 16.4 & 31.1 & 20.85 \\
\hline $\mathrm{Ca}, \%$ of DM & 0.26 & 1.47 & 1.27 \\
\hline P, $\%$ of DM & 0.24 & 0.33 & 0.38 \\
\hline $\mathrm{Mg}, \%$ of $\mathrm{DM}$ & 0.13 & 0.29 & 0.29 \\
\hline $\mathrm{K}, \%$ of DM & 1.05 & 2.68 & 2.58 \\
\hline
\end{tabular}

${ }^{1}$ Group 1 and 2 received the same crop of corn silage ( $\mathrm{n}=8$ samples) but each group received different cuttings of alfalfa silage $(n=4$ samples per group).

${ }^{2} \mathrm{LCFA}=$ long-chain fatty acids; residual organic matter $(\mathrm{ROM})=$ $100-\% \mathrm{CP}-\% \mathrm{LCFA}-\%$ ash $-\%$ starch $-\% \mathrm{NDF}$.

${ }^{3}$ The SD of the CP in corn silage was 0.38 , and for group 1 and 2 alfalfa silage was 1.03 and 1.34, respectively.

${ }^{4} \mathrm{NDF}_{\mathrm{om}+\mathrm{cp}}=\mathrm{NDF}-\mathrm{NDI}$-ash (ashed NDF residues) - NDICP (NDF residues analyzed for $\mathrm{CP}$ ); $\mathrm{ROM}_{\mathrm{om}+\mathrm{cp}}=100-\% \mathrm{CP}-\% \mathrm{LCFA}-\%$ ash $-\%$ starch $-\% \mathrm{NDF}_{\mathrm{om}+\mathrm{cp}}$. 
$\mathrm{h}$ before feeding from the tail vein into sodium heparin vacutainers (BD Vacutainer, Franklin Lakes, NJ). Plasma was separated by centrifugation $(2,500 \times g$ at $4^{\circ} \mathrm{C}$ for $20 \mathrm{~min}$ ) and frozen at $-20^{\circ} \mathrm{C}$ before analysis. Analyses included albumin (Albumin LiquiColor No. 0285), total protein (Total Protein LiquiColor No. 0250), glucose (Glucose LiquiColor No. 1070, Stanbio Laboratory, Boerne, TX), fatty acids [NEFA-HR(2), Wako Chemicals, Richmond, VA], and insulin (\#PI12K Porcine Insulin RIA, EMD Millipore, St. Charles, MO). Subsamples of plasma collected from consecutive days at the end of treatment feeding were also analyzed for AA using liquid chromatography tandem MS (Heartland Assays LLC, Ames, IA).

For apparent nutrient digestibility and $\mathrm{N}$ balance, total output of feces and urine was measured on 24 cows (2 primiparous and 6 multiparous blocks) following methods described by Weiss et al. (2009). After at least $20 \mathrm{~d}$ on experimental diets, 2 blocks of cows were moved from tiestalls to digestion stalls. Because only 6 digestion stalls were available, 2 blocks of cows were moved for each of the 4 digestion trials (2 trials per group). Urine ( $\mathrm{pH}$ kept below 3 by acidifying with $50 \%$ sulfuric acid), feces, milk, refusals, and feeds were sampled daily (refrigerated between days) and composited by wet weight across the 4-d collection period. In 3 of the 4 digestion trials (one set of samples were missed because of a scheduling error), daily subsamples of all feeds were taken and analyzed for $\mathrm{CP}$ (Kjeldahl $\mathrm{N} \times$ 6.25; AOAC International, 2000; 984.13.4.09) to evaluate day-to-day variation in diet composition. To reduce diet sorting during total collection, feed delivery was reduced so that refusal rate was 1 to $3 \%$. Daily water intake was measured with water meters connected to each individual water bowl.

Milk, acidified urine, and wet feces composite samples were analyzed for N (Kjeldahl method) immediately following each digestion period. Acidified urine was also frozen and later analyzed for creatinine (creatinine urinary assay no. 500701, Cayman Chemical Co., Ann Arbor, MI), uric acid (Uric Acid LiquiColor No. 1045, Stanbio Laboratory, Boerne, TX), allantoin (Chen, 1989), and carbon using an elemental analyzer (Flash 2000, Thermo Fisher Scientific, Waltham, MA) after oven-drying the urine (Morris et al., 2019a). Subsamples of concentrates and silages (digestion and monthly composite samples), refusal, and fecal composites were analyzed for $\mathrm{DM}\left(100^{\circ} \mathrm{C}\right.$ for $\left.48 \mathrm{~h}\right)$. The remaining silage, fecal, and refusal composite samples were frozen, lyophilized, and ground through a 1-mm screen (Wiley mill, Arthur H. Thomas Co., Philadelphia, PA). Concentrates and ground samples of silages, feces, and refusals were assayed for $\mathrm{DM}\left(100^{\circ} \mathrm{C}\right.$ for 24 h), ash (muffle oven at $600^{\circ} \mathrm{C}$ overnight), CP (Kjeldahl
$\mathrm{N} \times 6.25$ ), long-chain fatty acids (LCFA; Weiss and Wyatt, 2003), starch (Weiss and Wyatt, 2000) with modifications as stated in Tebbe et al. (2018), and NDF (Ankom200 Fiber Analyzer, Ankom Technology Corp., Fairport, NY) with sodium sulfite and amylase (Sigma A3306, Sigma Diagnostics, St. Louis, MO). The NDF residues were ashed (NDI-Ash; muffle oven at $600^{\circ} \mathrm{C}$ overnight) or analyzed for CP (NDICP; Kjeldahl N $\times$ 6.25). The NDI-ash and NDICP values were used to calculate NDF and residual organic matter (ROM, \% of $\mathrm{DM}=100-\% \mathrm{CP}-\% \mathrm{LCFA}-\%$ ash $-\%$ starch - \%NDF) as ash-free, CP-free, or both to correct for double subtraction of ash and CP in ROM (Tebbe et al., 2017). Dried, ground feed samples were analyzed for minerals (OARDC STAR Laboratory, Wooster, OH) by inductively coupled plasma emission spectroscopy (Isaac and Johnson, 1985) after microwave digestion in nitric acid (Jones et al., 1991).

\section{Body Composition}

Body composition was estimated during the covariate period and 1 to $2 \mathrm{~d}$ after treatment feeding ended using the urea dilution method (Agnew et al., 2005). Cows were weighed the day before and day of infusion, and body condition ( 1 to 5 scale) was scored by 4 trained individuals. Approximately $4 \mathrm{~h}$ after feeding, cows were moved to a chute and restrained with a halter to expose the jugular vein. A $10-\times 10-\mathrm{cm}$ area around the jugular vein was shaved, scrubbed twice with $7.5 \%$ povidone iodine and $70 \%$ alcohol, and an injection with $1.5 \mathrm{~mL}$ of $2 \%$ lidocaine- $\mathrm{HCl}$ was made subcutaneous and superficial to the jugular vein. The area was scrubbed again followed by a $1-\mathrm{cm}$ incision made with a scalpel blade on the injection site and insertion of a catheter (14-gauge $\times 133-\mathrm{mm}, 219 \mathrm{~mL} /$ min capacity; BD Angiocath, BD Infusion Therapy Systems, Sandy, UT) into the jugular vein. A small amount of blood was allowed to flush the tubing attached to the catheter before a baseline blood sample was taken. Using 200-mL syringes, cows were infused with a weighed amount of sterile, urea solution $(0.9 \%$ $\mathrm{NaCl}$ and 20\% wt/vol urea; reagent grade from Fisher Chemical, Fair Lawn, NJ). Infusion amount was 130 $\mathrm{mg}$ of urea $/ \mathrm{kg}$ of BW $(0.65 \mathrm{~mL}$ of solution $/ \mathrm{kg}$ of BW) and was infused over 2 to $3 \mathrm{~min}$. After infusion, the tubing was immediately flushed with heparinized saline (10 IU of heparin $/ \mathrm{mL}$ and $0.9 \% \mathrm{NaCl}$ ), the catheter was removed, and the incision site was closed with tissue adhesive (Vetbond, 3M Animal Care Products, St. Paul, MN) and sprayed with aerosol bandage (AluShield, Neogen Corp., Lexington, KY). Cows were returned to tiestalls, and another blood sample was collected from the coccygeal vein promptly at $12 \mathrm{~min}$ 
after infusion. All blood samples were collected into sodium heparin vacutainers and immediately placed on ice. Plasma was separated by centrifugation (described above) and frozen at $-20^{\circ} \mathrm{C}$ until urea concentration was measured using a colorimetric method (SKU\# UR1068, Randox Laboratories Ltd., Crumlin, UK).

Urea space volume was calculated as the quantity of urea infused divided by the difference in urea concentration from baseline and postinfusion plasma samples. Urea space volume, average body condition and BW, and the previous week's average milk yield were then used to calculate empty BW, CP, lipid, ash, gross energy, and water using equations $7 \mathrm{~d}, 8,9 \mathrm{~d}, 11 \mathrm{~d}$, and 12 , respectively, from Agnew et al. (2005). In addition to BW collected for body composition measurements, BW was measured on consecutive mornings on d 24 and 25 (group 1) and d 27 and 28 (group 2), averaged, and used for statistical analysis.

\section{Calculations and Statistical Analyses}

For statistical analyses, production measurements were averaged within cow for the covariate period and weekly for the treatment period (7 wk total). To evaluate the effect of oscillation phase on production and blood measurements, all measurements taken on days designated as high within the oscillation cycle were averaged within cow as were measurements on days designated as low. To assess insulin resistance of peripheral tissues, the homeostasis model assessment of insulin resistance (HOMA-IR) and the revised quantitative insulin sensitivity check index (RQUICKI) were calculated according to De Koster and Opsomer (2013). Insulin resistance was investigated because high protein diets have been associated with greater insulin resistance in humans (Rietman et al., 2014). Apparent digestibility and $\mathrm{N}$ metabolism measurements were calculated for each cow, and digestible energy (DE; $\mathrm{Mcal} / \mathrm{d}$ ) was estimated using intakes of digestible nutrients and enthalpies stated in Tebbe et al. (2018). Diet $\mathrm{NE}_{\mathrm{L}}$ concentrations were estimated 2 ways. First, $\mathrm{NE}_{\mathrm{L}}$ was calculated by subtracting estimated urine (Hoffmann and Klein, 1980) and methane energy (Nielsen et al., 2013) from DE (all expressed as Mcal/d), then multiplying by an assumed efficiency of 0.66 (Agnew and Yan, 2000) and dividing by daily DMI. Treatment $\mathrm{NE}_{\mathrm{L}}$ was also calculated by summing estimated energy expenditures (i.e., maintenance, lactation, and BW changes) and dividing by DMI measured over the 50-d experiment: $\mathrm{NE}_{\mathrm{L}}, \mathrm{Mcal} / \mathrm{d}=0.1 \times \mathrm{BW}^{0.75}+\mathrm{BW}$ change $\times 5.6+$ milk energy, where maintenance energy is from Ellis et al. (2006) and BW and milk energies are from NRC (2001).
Two multiparous cows (one on 109MP and one on OSC) developed chronic mastitis during treatment feeding and were removed during the experiment; data were not used from either cow. All statistical analyses were made using PROC MIXED (version 9.4, SAS Institute Inc., Cary, NC). The model for average daily production, BW, and blood data included the fixed effects of treatment, week (repeated), their interaction, and the random effects of group, block within a group, block $\times$ treatment, and residual error. The model used to analyze the effect of oscillation phase included the fixed effects of treatment, OSC phase (i.e., high or low), and their interaction, the random effects of group, block within a group, cow within a group by treatment, and residual error. When the treatment by phase interaction was significant $(P<0.10)$, the SLICE option was used to determine whether phase had an effect within dietary treatment. For digestibility, balance, and body composition measurements, the model included the fixed effect of treatment and random effects of block and residual error. Body composition, blood metabolites (except AA concentrations), and production least squares means were covariate adjusted from measurements taken during the covariate period. The autoregressive covariance structure was used for repeated measurements based on lowest Bayesian information criterion. Denominator degrees of freedom were adjusted using the Kenward-Roger option. Two nonorthogonal contrasts were chosen a priori and used to evaluate effect of CP concentration (109MP vs. 95MP) and effect of oscillation (95MP vs. OSC). The homogeneity of treatment variances on production measurements was assessed using the GROUP option of the MIXED procedure. The Bayesian information criterion of production measurements and the interpretation of treatments were similar whether the variances were separated by treatment or combined. The highest standard error of the mean was reported for all measurements because of missing data.

\section{RESULTS AND DISCUSSION}

The low phase OSC diet had about $25 \%$ less CP and $15 \%$ less ROM, whereas NDF and starch concentrations were both about $12 \%$ greater compared with the high phase OSC (Table 2). Based on actual production and DMI, the 109MP, 95MP, and OSC treatments (on average) provided, respectively, 109, 95, and 95\% of $\mathrm{MP}$, and 99,86 , and $86 \%$ of RDP requirements (NRC, 2001). When cows on OSC were fed the low phase OSC diet and using the average production and DMI from that day, the diet provided $78 \%$ of MP and $73 \%$ of RDP requirements. As designed, the day-to-day coefficient 
of variation in dietary $\mathrm{CP}$ was considerably higher for OSC (17.0\%) compared with 95MP (3.4\%) and 109MP $(1.3 \%)$. The coefficients of variation were calculated from daily samples taken during the 4-d total collection experiments.

\section{Production}

Compared with 109MP, feeding 95MP continuously did not influence DMI, but as designed, reduced $(P$ $=0.02$ ) milk yield $1.5 \mathrm{~kg} / \mathrm{d}$ (Table 4 ). As expected, production was similar for each phase (i.e., days when OSC were fed high or low phase OSC diets) for the 109MP and 95MP treatments $(P \geq 0.15$; Table 5$)$. For OSC, DMI was numerically reduced $(P=0.11)$ and milk yield was similar to feeding 95MP. During the 4-d digestion trials, DMI was lower (Table 6) for OSC than 95MP. Within the OSC treatment, phase did not affect DMI; however, milk yield was $1.5 \mathrm{~kg} / \mathrm{d}$ higher $(P<$ 0.01) during the low phase compared with the high phase OSC diet.

In longer term experiments with growing ruminants, DMI has been similar (Ludden et al., 2002a; Doranalli et al., 2011) or tended to decrease (Doranalli et al., 2011) when oscillating CP concentrations every $48 \mathrm{~h}$ compared with feeding a similar average CP concentration continuously. Dietary factors that can affect DMI include RDP deficiencies (Oldham, 1984) and increasing inclusion rate of soyhulls (Ipharraguerre et al., 2002), which occurred when cows changed from high phase to low phase. Those dietary effects on DMI could be mediated via reduced NDF digestibility; however, treatment did not affect NDF digestibility (Table 6). Supply of AA can also affect DMI (Lee et al., 2012) but treatments and day of oscillation phase had only minor effects on plasma AA concentrations (Table 7; Supplemental Table S3; https://doi.org/10.3168/jds .2020-18613). The reasons for why OSC likely reduced DMI compared with $95 \mathrm{MP}$ are not known.

Yields of ECM, milk fat, and milk energy as well as their concentrations in milk were not affected by treatment (Table 4). Milk protein concentration was reduced $(P<0.04)$ for both 109MP and OSC treatments compared with 95MP; however, milk protein yield was unaffected by $\mathrm{CP}$ concentration or oscillation $(P>$ 0.17 ). Yield of lactose increased for 109MP but was similar between 95MP and OSC. Similar to milk yield, cows fed OSC had higher $(P=0.04)$ yield of milk protein and tended to have greater $(P=0.10)$ milk lactose yield during the low phase compared with high phase of the oscillation (Table 5). However, yields of ECM and milk fat were similar $(P \geq 0.51)$ between the high and low days for OSC. Daily changes in milk protein yields but not for milk fat or ECM yields suggests MP supply was the limiting nutrient for milk production and that cows require a continuous dietary supply of MP. This means protein stores (e.g., skeletal muscle) cannot rapidly supply enough AA to spare a short-term deficiency in MP supply.

Milk urea $\mathrm{N}$ concentration was the only production response that had a treatment by week interaction $(P$ $<0.01$ ). At all weeks except wk 2 and 7 , MUN con-

Table 4. Effects of static or oscillating CP concentrations on intake and production for the 50-d experiment

\begin{tabular}{|c|c|c|c|c|c|c|}
\hline Item & \multicolumn{3}{|c|}{ Treatment $^{1}$} & SEM & \multicolumn{2}{|c|}{$P$-value ${ }^{2}$} \\
\hline $\mathrm{ECM}^{3}, \mathrm{~kg} / \mathrm{d}$ & 36.3 & 34.9 & 33.8 & 1.89 & 0.19 & 0.35 \\
\hline ECM/DMI & 1.59 & 1.52 & 1.52 & 0.04 & 0.13 & 0.98 \\
\hline Milk fat, $\%$ & 3.22 & 3.36 & 3.10 & 0.17 & 0.45 & 0.17 \\
\hline Milk energy, ${ }^{4} \mathrm{Mcal} / \mathrm{kg}$ & 0.67 & 0.68 & 0.66 & 0.01 & 0.52 & 0.21 \\
\hline Milk fat, kg/d & 1.21 & 1.19 & 1.10 & 0.09 & 0.77 & 0.27 \\
\hline Milk protein, $\mathrm{kg} / \mathrm{d}$ & 1.10 & 1.06 & 1.05 & 0.06 & 0.14 & 0.59 \\
\hline Milk lactose, $\mathrm{kg} / \mathrm{d}$ & 1.82 & 1.69 & 1.73 & 0.05 & 0.01 & 0.24 \\
\hline Milk energy, ${ }^{4} \mathrm{Mcal} / \mathrm{d}$ & 24.7 & 23.7 & 23.0 & 1.21 & 0.18 & 0.38 \\
\hline $\mathrm{MUN},{ }^{5} \mathrm{mg} / \mathrm{dL}$ & 12.8 & 10.2 & 10.9 & 0.74 & 0.01 & 0.10 \\
\hline
\end{tabular}

${ }^{1} 109 \mathrm{MP}=$ high phase OSC diet fed continuously; $95 \mathrm{MP}=50: 50 \mathrm{mix}$ of high and low phase OSC diets fed continuously; OSC $=$ oscillating from the high phase OSC diet to low phase OSC diet on a 24-h basis. All LSM were covariate adjusted.

${ }^{2} \mathrm{CP}$ concentration: $109 \mathrm{MP}$ vs. $95 \mathrm{MP}$, positive control $(16 \% \mathrm{CP})$ vs. negative $\mathrm{CP}$ control $(14 \% \mathrm{CP})$; oscillation: $95 \mathrm{MP}$ vs. OSC, negative control $(14 \% \mathrm{CP})$ vs. oscillating CP $(14 \% \mathrm{CP})$.

${ }^{3} \mathrm{ECM}, \mathrm{kg} / \mathrm{d}=0.327 \times$ milk yield $+12.95 \times$ fat yield $+7.65 \times$ protein yield (Tyrrell and Reid, 1965).

${ }^{4}$ Calculated according to NRC (2001).

${ }^{5}$ Treatment $\times$ week interaction $(P<0.01)$. 
Table 5. Effects of static or oscillating CP concentrations on day-to-day differences in intake, milk production, and blood metabolites ${ }^{1}$

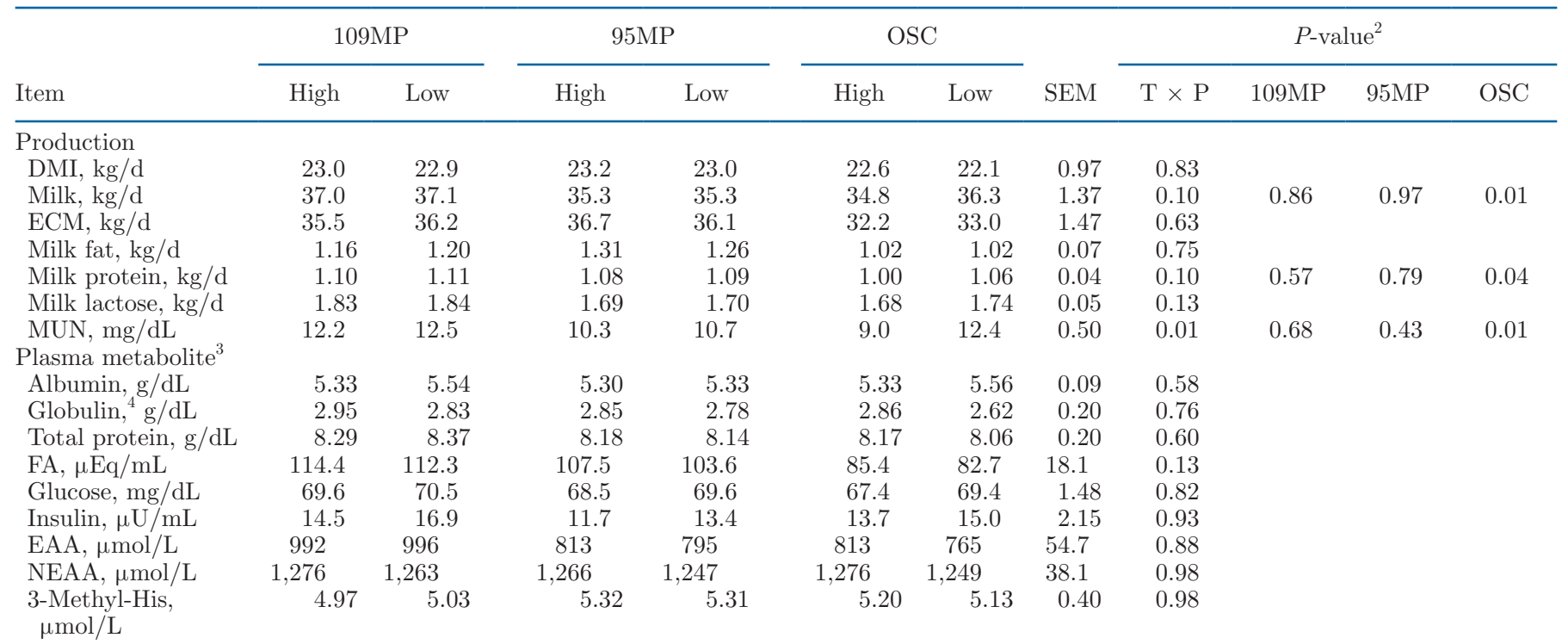

${ }^{1}$ Averages of high or low day of OSC within a treatment and for the 50-d treatment period. Day of OSC is whether cows on the OSC treatment were on the high phase OSC diet or low phase OSC diet. All LSM were covariate adjusted to measurements taken before treatment feeding except for plasma AA. 109MP = high phase OSC diet fed continuously; 95MP = 50:50 mix of high and low phase OSC diets fed continuously; OSC $=$ oscillating from the high phase OSC diet to low phase OSC diet on a 24-h basis.

${ }^{2}$ The interaction of treatment and oscillation phase $(\mathrm{T} \times \mathrm{P})$. If the interaction was significant $(P<0.10)$, then the SLICE option $(\mathrm{SAS}$ version 9.4, SAS Institute Inc., Cary, NC) was used to determine whether response variables differed across phases within a dietary treatment. The $P$-values under treatment columns are to evaluate differences between phases.

${ }^{3}$ Plasma metabolites are from samples taken on consecutive mornings during the middle (group 1: d 24 and 25; group 2: d 27 and 28) and end of treatment feeding (d 49 and 50). For plasma AA, samples were taken at the end of treatment feeding (d 49 and 50). FA = fatty acids.

${ }^{4}$ Globulin, $\mathrm{g} / \mathrm{dL}=$ total protein, $\mathrm{g} / \mathrm{dL}-$ albumin, $\mathrm{g} / \mathrm{dL}$.

centration was greater for cows fed 109MP and lowest for cows fed $95 \mathrm{MP}$; the lack of a discernable pattern suggests the week by treatment interaction is probably not important biologically. Concentration of MUN was about $2.6 \mathrm{mg} / \mathrm{dL}$ greater $(P<0.01)$ for cows fed 109MP compared with $95 \mathrm{MP}$, which agrees closely with values obtained from the prediction equation of Jonker et al. (1998). The MUN concentration also increased numerically $(P=0.10)$ for OSC compared with 95MP. Higher MUN concentration occurred despite similar milk and milk protein yields and less $\mathrm{N}$ intake for OSC compared with 95MP. The MUN concentration of cows fed OSC was also higher during the low phase compared with high phase diet (Table 5). Because MUN concentration is highly correlated with blood urea concentration (Broderick and Clayton, 1997), urea recycling to the rumen may have been increased when cows were fed the low phase diet (Doranalli et al., 2011), but the urea was not well utilized for microbial CP synthesis.

\section{Plasma Metabolite and AA Concentrations}

Plasma concentrations and indices of energy and protein metabolites were similar between 109MP and $95 \mathrm{MP}$ and for $95 \mathrm{MP}$ and OSC (Table 8). Low protein diets (12.7 vs. $16.6 \% \mathrm{CP}$ ) have reduced plasma albumin but not total protein concentrations in mid-lactation cows (Raggio et al., 2007). In our study the 95MP or OSC were only $5 \%$ deficient in MP compared with over $20 \%$ deficiency in Raggio et al. (2007), which may be the reason we did not observe a treatment effect on plasma proteins. Plasma concentrations of fatty acids, glucose, and insulin as well as indices of insulin resistance (i.e., HOMA-IR) and sensitivity (i.e., RQUICKI) were unaffected likely because energy balance was positive and similar among treatments. Lack of treatment effects on plasma energy metabolites and indices support the lack of differences in change in body composition (discussed below, Table 9), BCS, BW, and milk energy yields. These data in total indicate that partitioning of $\mathrm{NE}_{\mathrm{L}}$ to the mammary gland and peripheral tissues was not altered by treatments. Plasma metabolites did not differ $(P \geq 0.13)$ between high and low days for the OSC treatment, although some $\mathrm{N}$ metabolites (e.g., total protein and AA) appear numerically lower on low versus high days of OSC (Table 5), which was opposite of what was observed for milk production.

Plasma concentrations of several EAA (Arg, His, Iso, Leu, Lys, and Val; Table 7) and NEAA (Ala, Glu, Gln, and Pro) were less $(P \leq 0.05)$ for 95MP than for 
Table 6. Effects of static or oscillating CP concentrations on manure output, DM and water intake, and nutrient digestibility

\begin{tabular}{|c|c|c|c|c|c|c|}
\hline Item & \multicolumn{3}{|c|}{ Treatment $^{1}$} & SEM & \multicolumn{2}{|c|}{$P$-value ${ }^{2}$} \\
\hline \multicolumn{7}{|l|}{ Water intake, $\mathrm{kg} / \mathrm{d}$} \\
\hline Free & 108.8 & 100.0 & 94.4 & 5.10 & 0.09 & 0.24 \\
\hline Total & 136.4 & 128.5 & 120.9 & 5.70 & 0.15 & 0.15 \\
\hline \multicolumn{7}{|l|}{ Output, $\mathrm{kg} / \mathrm{d}$ (as-is) } \\
\hline Fecal water & 40.9 & 43.8 & 40.7 & 2.45 & 0.18 & 0.13 \\
\hline Urine & 25.2 & 17.8 & 19.4 & 2.81 & 0.07 & 0.67 \\
\hline Total manure & 72.9 & 68.8 & 66.6 & 3.28 & 0.30 & 0.56 \\
\hline DM intake, $\mathrm{kg} / \mathrm{d}$ & 21.5 & 22.6 & 20.9 & 0.74 & 0.16 & 0.03 \\
\hline \multicolumn{7}{|c|}{ Apparent digestibility, ${ }^{3} \%$} \\
\hline DM & 69.5 & 68.1 & 68.5 & 0.78 & 0.19 & 0.70 \\
\hline $\mathrm{OM}$ & 70.7 & 69.0 & 69.4 & 0.79 & 0.14 & 0.72 \\
\hline ROM & 71.1 & 66.5 & 65.3 & 2.50 & 0.16 & 0.69 \\
\hline $\mathrm{ROM}_{\mathrm{om}+\mathrm{c}}{ }^{4}$ & 69.0 & 65.5 & 64.1 & 2.12 & 0.21 & 0.58 \\
\hline
\end{tabular}

${ }^{1} 109 \mathrm{MP}=$ high phase OSC diet fed continuously; $95 \mathrm{MP}=50: 50$ mix of high and low phase OSC diets fed continuously; OSC $=$ oscillating from the high phase OSC diet to low phase OSC diet on a 24 -h basis.

${ }^{2} \mathrm{CP}$ concentration: $109 \mathrm{MP}$ vs. $95 \mathrm{MP}$, positive control $(16 \% \mathrm{CP})$ vs. negative $\mathrm{CP}$ control $(14 \% \mathrm{CP})$; oscillation: $95 \mathrm{MP}$ vs. OSC, negative control $(14 \% \mathrm{CP})$ vs. oscillating CP $(14 \% \mathrm{CP})$.

${ }^{3} \mathrm{LCFA}=$ long-chain fatty acid; $\mathrm{ROM}=$ residual $\mathrm{OM}$.

${ }^{4} \mathrm{NDF}_{\mathrm{om}+\mathrm{cp}}=\mathrm{NDF}-\mathrm{NDI}$-ash (ashed NDF residues) - NDICP (NDF residues analyzed for CP); $\mathrm{ROM}_{\mathrm{om}+\mathrm{cp}}=100-\% \mathrm{CP}-\% \mathrm{LCFA}-\%$ ash $\%$ starch $-\% \mathrm{NDF}_{\text {om+cp }}$.

109MP. Citrulline and ornithine, intermediate AA in the urea cycle, were also lower $(P \leq 0.05)$ for $95 \mathrm{MP}$ compared with 109MP. Decreases in these plasma AA with a lower MP supply are in line with other studies (Lee et al., 2012; Giallongo et al., 2015). For OSC treatment, dietary $\mathrm{CP}$ changed markedly day to day, but plasma concentrations of most AA were remarkably similar over the oscillation cycle (Table 5, Supplemental Table S3; https://doi.org/10.3168/jds.2020-18613). To our knowledge, no previous studies oscillating CP concentrations in ruminants have measured AA concentrations or day-to-day changes of AA concentrations in plasma. Except for Arg and Thr, average plasma concentrations across high and low days of OSC were similar for all AA $(P \geq 0.15)$ between $95 \mathrm{MP}$ and OSC. Arginine can be endogenously synthesized in the intestine, is essential for the urea cycle, and can serve as an $\mathrm{N}$ reservoir (Wu, 2009). Plasma Arg numerically increased $(P=0.11)$ for OSC compared with 95MP, but the reason is unknown. Conversely, Thr tended to decrease $(P=0.09)$ when oscillating $C P$. In addition to milk protein, Thr is used largely to synthesize mucin proteins required to maintain gut integrity and function (Wu, 2009). However, Thr is likely not a limiting AA for milk protein synthesis (Doepel et al., 2016). Plasma concentrations of 3-methyl-L-His, a biomarker for muscle catabolism, were similar between OSC and 95MP indicating endogenous stores (i.e., skeletal muscle) were probably not supplying extra AA for milk production when oscillating CP. Moreover, plasma 3-methyl-His concentrations were similar between high and low days of oscillation for OSC (Table 5). The lack of differences in 3-methyl-His provides additional evidence that protein stores cannot rapidly buffer a temporary reduction in MP supply.

\section{Nutrient Intake and Apparent Digestibility}

During the 4-d total collection period (Table 6), DMI was similar between 109MP and 95MP but about 0.7 $\mathrm{kg} / \mathrm{d}$ less $(P<0.03)$ for OSC compared with 95MP. Milk yield during the digestion trial followed the same pattern as during the production experiment (Table 4), but because of less statistical power and the short duration (4 d) no statistical differences were observed.

Free water intake and urine output tended to increase $(P \leq 0.09)$ for $109 \mathrm{MP}$ versus $95 \mathrm{MP}$. This agrees with other findings where dietary $\mathrm{CP}$ concentrations have been positively correlated with free water intake (Holter and Urban, 1992) and urine output (Bannink 
Table 7. Effects of static or oscillating CP concentrations on average plasma AA concentrations ${ }^{1}$

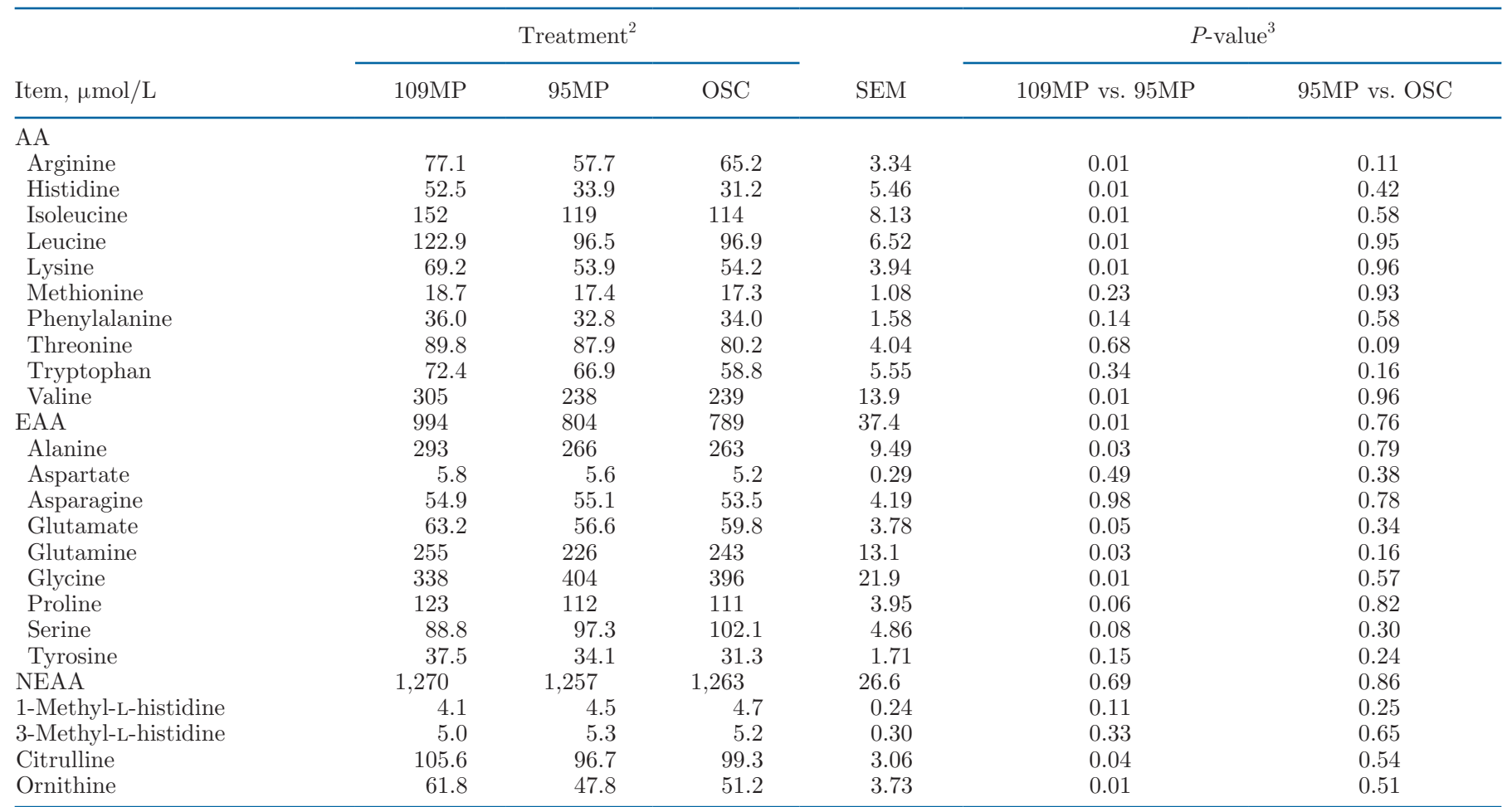

${ }^{1}$ Plasma AA were from samples taken at the end of treatment feeding (d 49 and 50). Averages calculated across the consecutive days of sampling. ${ }^{2} 109 \mathrm{MP}=$ high phase OSC diet fed continuously; $95 \mathrm{MP}=50: 50 \mathrm{mix}$ of high and low phase OSC diets fed continuously; OSC $=$ oscillating from the high phase OSC diet to low phase OSC diet on a 24-h basis.

${ }^{3} \mathrm{CP}$ concentration: $109 \mathrm{MP}$ vs. $95 \mathrm{MP}$, positive control $(16 \% \mathrm{CP})$ vs. negative $\mathrm{CP}$ control $(14 \% \mathrm{CP})$; oscillation: $95 \mathrm{MP}$ vs. OSC, negative control $(14 \% \mathrm{CP})$ vs. oscillating CP $(14 \% \mathrm{CP})$.

Table 8. Effects of static or oscillating CP concentrations on the plasma concentration of energy- and protein-related metabolites ${ }^{1}$

\begin{tabular}{|c|c|c|c|c|c|c|}
\hline Item & \multicolumn{3}{|c|}{ Treatment $^{2}$} & SEM & \multicolumn{2}{|c|}{$P$-value ${ }^{3}$} \\
\hline Albumin, $\mathrm{g} / \mathrm{dL}$ & 5.44 & 5.32 & 5.40 & 0.06 & 0.15 & 0.34 \\
\hline Total protein, g/dL & 8.33 & 8.16 & 8.12 & 0.19 & 0.41 & 0.87 \\
\hline $\mathrm{FA},{ }^{5} \mu \mathrm{Eq} / \mathrm{mL}$ & 98.4 & 105.6 & 84.1 & 17.1 & 0.64 & 0.20 \\
\hline Glucose, $\mathrm{mg} / \mathrm{dL}$ & 70.1 & 69.1 & 68.4 & 1.32 & 0.58 & 0.71 \\
\hline RQUICKI $^{7}$ & 0.204 & 0.206 & 0.210 & 0.004 & 0.65 & 0.48 \\
\hline
\end{tabular}

${ }^{1}$ Plasma metabolites are from samples taken on consecutive mornings during the middle (group 1: d 24 and 25; group 2: d 27 and 28) and end of treatment feeding (d 49 and 50). All LSM were covariate adjusted to plasma samples taken before treatment feeding.

${ }^{2} 109 \mathrm{MP}=$ high phase OSC diet fed continuously; $95 \mathrm{MP}=50: 50 \mathrm{mix}$ of high and low phase OSC diets fed continuously; OSC $=$ oscillating from the high phase OSC diet to low phase OSC diet on a 24-h basis.

${ }^{3} \mathrm{CP}$ concentration: $109 \mathrm{MP}$ vs. $95 \mathrm{MP}$, positive control $(16 \% \mathrm{CP})$ vs. negative $\mathrm{CP}$ control $(14 \% \mathrm{CP})$; oscillation: $95 \mathrm{MP}$ vs. OSC, negative control $(14 \% \mathrm{CP})$ vs. oscillating $\mathrm{CP}(14 \% \mathrm{CP})$.

${ }^{4}$ Globulin, $\mathrm{g} / \mathrm{dL}=$ total protein, $\mathrm{g} / \mathrm{dL}-$ albumin, $\mathrm{g} / \mathrm{dL}$.

${ }^{5} \mathrm{FA}=$ fatty acids.

${ }^{6}$ Homeostasis model assessment of insulin resistance $($ HOMA-IR $)=[$ glucose $(\mathrm{mg} / \mathrm{dL}) \times$ insulin $(\mu \mathrm{U} / \mathrm{mL})] / 405$. Higher HOMA-IR means greater insulin resistance.

${ }^{7}$ Revised quantitative insulin sensitivity check index (RQUICKI) $=[\log \text { glucose }(\mathrm{mg} / \mathrm{dL})+\log \text { insulin }(\mu \mathrm{U} / \mathrm{mL})+\log \mathrm{FA}(\mu \mathrm{Eq} / \mathrm{L})]^{-1} \mathrm{Lower}$ RQUICKI means greater insulin sensitivity. 
Table 9. Effects of static or oscillating CP concentrations on body composition measured using urea dilution method ${ }^{1}$

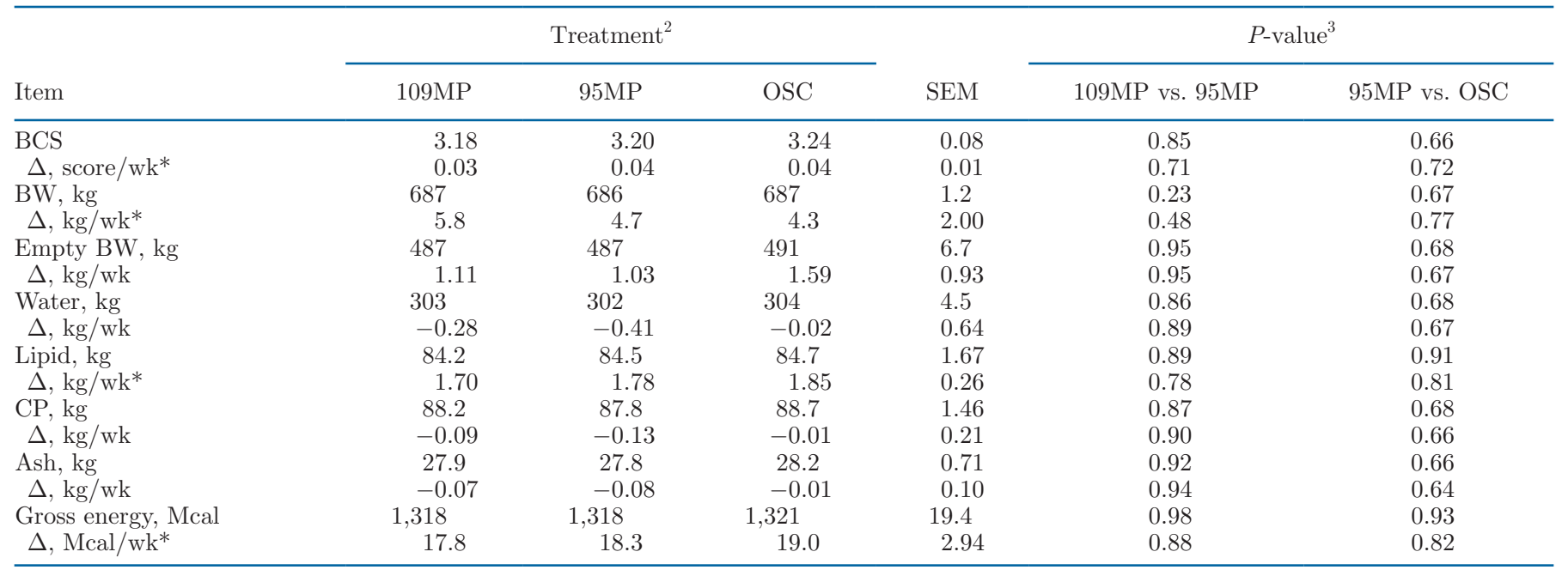

${ }^{1}$ Body composition measurements are calculated using the equations in Agnew et al. (2005) and covariate adjusted to measurements taken before treatment feeding. Change $(\Delta)$ in body composition is unadjusted and is calculated as the difference between measurements taken before and after treatment feeding.

${ }^{2} 109 \mathrm{MP}=$ high phase OSC diet fed continuously; $95 \mathrm{MP}=50: 50 \mathrm{mix}$ of high and low phase OSC diets fed continuously; OSC $=$ oscillating from the high phase OSC diet to low phase OSC diet on a 24-h basis.

${ }^{3} \mathrm{CP}$ concentration: $109 \mathrm{MP}$ vs. $95 \mathrm{MP}$, positive control $(16 \% \mathrm{CP})$ vs. negative $\mathrm{CP}$ control $(14 \% \mathrm{CP})$; oscillation: $95 \mathrm{MP}$ vs. OSC, negative control $(14 \% \mathrm{CP})$ vs. oscillating $\mathrm{CP}(14 \% \mathrm{CP})$.

*Means within a row were all different from $0(P<0.05)$.

et al., 1999). Total water intake and output of manure were not affected by MP or oscillation $(P>0.15)$.

Intakes of OM, LCFA, and ROM were similar between 109MP and 95MP, whereas intakes of CP, starch, and NDF reflected changes in their dietary concentrations between treatments (data not shown). Digestibility of most nutrients was similar between 109MP and 95MP with the exception of $\mathrm{CP}$, which was decreased when lowering the $\mathrm{CP}$ concentration. Apparent $\mathrm{CP}$ digestibility usually increases when dietary $\mathrm{CP}$ concentration increases because metabolic fecal CP is diluted (Holter and Reid, 1959). Low CP ( $<15 \%$ of DM) and RDP $(<10 \%$ of DM) concentrations can reduce NDF digestibility (Broderick et al., 2008; Lee et al., 2011). Similar NDF digestion suggests RDP may not have been deficient for $95 \mathrm{MP}$ or more urea was recycled to the rumen for $95 \mathrm{MP}$ versus 109MP.

Average nutrient concentrations between 95MP and OSC were similar; however, the decrease in DMI for OSC caused intake of major nutrients to decrease $(P \leq$ 0.04 ) around $8 \%$ compared with $95 \mathrm{MP}$ during the total collection period (data not shown). Except for CP, digestibility of major nutrients was similar between $95 \mathrm{MP}$ and OSC. The digestibility of CP increased from 61.7 to $65.3 \%$ when oscillating $\mathrm{CP}$ concentrations. In previous studies, digestibility of DM and different carbohydrate fractions was similar whether $\mathrm{CP}$ concentrations were oscillated or static; however, oscillating $\mathrm{CP}$ on a $48-\mathrm{h}$ basis versus feeding a similar average $\mathrm{CP}$ concentration continuously has increased (Archibeque et al., 2007a; Kiran and Mutsvangwa, 2009; Doranalli et al., 2011), not affected (Cole, 1999; Ludden et al., 2002b; Cole et al., 2003; Menezes et al., 2019), or decreased CP digestibility (Ludden et al., 2002a). Dissimilar results are likely from the wide range of diets fed and different manipulations of other nutrients when oscillating CP (i.e., starch, NDF, RDP, RUP). In studies that observed greater $\mathrm{CP}$ digestibility, protein sources with moderate to low ruminal CP degradability (e.g., canola, soybean, or corn gluten meal) were oscillated with starch sources (e.g., ground corn or barley). In studies with similar $\mathrm{CP}$ digestibility, protein sources with moderate to low ruminal CP degradability and urea were oscillated with starch sources (e.g., ground corn or sorghum). In the only study with lower CP digestibility, a protein source high in RUP (i.e., expeller soybean meal) was oscillated with soybean meal, urea, and corn in low $\mathrm{CP}$ diets to make RDP equal. Our results partially agree with studies with increased CP digestibility since we oscillated soybean meal with corn grain and soyhulls and did not balance for RDP. Therefore, higher CP digestion may be observed when oscillating primarily RDP concentrations and highly digestible carbohydrates. More urea recycling to the rumen versus hindgut when oscillating CP concentrations as suggested by Cole (1999) could explain greater apparent digestibility of $\mathrm{CP}$. Because 
Table 10. Effects of static or oscillating CP concentrations on estimated dietary energy intakes and losses

\begin{tabular}{|c|c|c|c|c|c|c|}
\hline Item & \multicolumn{3}{|c|}{ Treatment $^{1}$} & SEM & \multicolumn{2}{|c|}{$P$-value ${ }^{2}$} \\
\hline DE intake, ${ }^{3} \mathrm{Mcal} / \mathrm{d}$ & 65.6 & 66.7 & 62.4 & 2.48 & 0.69 & 0.12 \\
\hline Urine energy, ${ }^{4} \mathrm{Mcal} / \mathrm{d}$ & 2.1 & 1.7 & 2.0 & 0.13 & 0.05 & 0.15 \\
\hline Methane energy, ${ }^{5} \mathrm{Mcal} / \mathrm{d}$ & 6.0 & 6.4 & 5.9 & 0.22 & 0.11 & 0.04 \\
\hline $\mathrm{NE}_{\mathrm{L}}{ }^{6} \mathrm{Mcal} / \mathrm{kg}$ of DM & 1.76 & 1.71 & 1.72 & 0.02 & 0.10 & 0.85 \\
\hline
\end{tabular}

${ }^{1} 109 \mathrm{MP}=$ high phase OSC diet fed continuously; 95MP = 50:50 mix of high and low phase OSC diets fed continuously; OSC = oscillating from the high phase OSC diet to low phase OSC diet on a 24-h basis.

${ }^{2} \mathrm{CP}$ concentration: $109 \mathrm{MP}$ vs. $95 \mathrm{MP}$, positive control $(16 \% \mathrm{CP})$ vs. negative $\mathrm{CP}$ control $(14 \% \mathrm{CP})$; oscillation: $95 \mathrm{MP}$ vs. OSC, negative control $(14 \% \mathrm{CP})$ vs. oscillating CP $(14 \% \mathrm{CP})$.

${ }^{3}$ Digestible energy (DE) intake (Mcal/d) calculated according to Tebbe et al. (2018).

${ }^{4}$ Estimated urine energy, Mcal/d $=0.033 \times$ urine C, g/d $+0.009 \times$ urine N, g/d from Hoffmann and Klein (1980).

${ }^{5}$ Predicted methane energy, Mcal $/ \mathrm{d}=\mathrm{DMI}, \mathrm{kg} / \mathrm{d} \times 0.294-0.347 \times$ long-chain fatty acids, \% of DM $+0.0287 \times \mathrm{NDF}, \%$ of DM from Nielsen et al. (2013).

${ }^{6} \mathrm{NE}_{\mathrm{L}}, \mathrm{Mcal} / \mathrm{kg}=[0.66 \times(\mathrm{DE}$ intake - urine energy - methane energy $)] / \mathrm{DMI}$.

${ }^{7} \mathrm{NE}_{\mathrm{L}}, \mathrm{Mcal} / \mathrm{kg}=\left(0.1 \times \mathrm{BW}^{0.75}+\mathrm{BW}\right.$ change $\times 5.6+$ milk energy $) / \mathrm{DMI}$. Calculated using energy outputs measured during treatment feeding. Maintenance energy is calculated according to Ellis et al. (2006) and BW and milk energies according to NRC (2001).

most metabolic fecal CP originates from bacteria, a reduction of urea recycled to the hindgut and less hindgut microbial CP synthesis could explain increased apparent $\mathrm{CP}$ digestibility when oscillating CP. The proposed mechanism as well as the degradability of CP sources and nutrients replacing $\mathrm{CP}$ when oscillating deserves more investigation.

\section{Energy and N Metabolism}

Gross feed efficiency was unaffected and averaged $1.54 \mathrm{~kg}$ of ECM $/ \mathrm{kg}$ of DMI across treatments. Intake of estimated DE was similar between 109MP and 95MP and averaged $66.2 \mathrm{Mcal} / \mathrm{d}$ (Table 10). Increasing dietary CP concentration often increases DM digestibility (Oldham, 1984) and presumably energy digestibility. Numerically less DMI for 109MP caused similar DE intakes because estimated DE concentration tended to be $0.1 \mathrm{Mcal} / \mathrm{kg}$ greater $(P=0.10)$ for $109 \mathrm{MP}$ versus 95MP. Increasing the $\mathrm{CP}$ concentration increased $(P$ $=0.05)$ estimated urinary energy but numerically decreased $(P=0.11)$ estimated methane losses. When assuming a constant efficiency of $0.66 \mathrm{Mcal}$ of $\mathrm{NE}_{\mathrm{L}} /$ Mcal of ME, this resulted in a tendency for greater $(P=0.10)$ estimated $\mathrm{NE}_{\mathrm{L}}$ concentration for 109MP compared with 95MP (Table 10). However, because diets with higher $\mathrm{CP}$ concentration may reduce the efficiency of converting $\mathrm{ME}$ to $\mathrm{NE}_{\mathrm{L}}$ (Reed et al., 2017; Morris et al., 2019b), our calculations may overestimate the $\mathrm{NE}_{\mathrm{L}}$ concentration for the $109 \mathrm{MP}$ diet relative to the $95 \mathrm{MP}$ treatments. When diet $\mathrm{NE}_{\mathrm{L}}$ was estimated from energy expenditures, dietary values were similar to those obtained from the method based on DE. In steers, oscillating CP compared with a similar average $\mathrm{CP}$ concentration fed continuously tended to reduce heat production $4 \%$ without affecting other energetic losses (Archibeque et al., 2007a). If this happened in our study, the OSC treatment would have reduced heat losses and improved efficiency of $\mathrm{ME}$ to $\mathrm{NE}_{\mathrm{L}}$ compared with $95 \mathrm{MP}$, and the estimated $\mathrm{NE}_{\mathrm{L}}$ for the OSC treatment would be underestimated relative to the $95 \mathrm{MP}$ treatment.

The greater mass of $\mathrm{N}$ absorbed for $109 \mathrm{MP}$ did not improve productive- $\mathrm{N}$ output $(P=0.40$; Table 11$)$ and instead increased urinary $\mathrm{N}$ excretion by $60 \mathrm{~g} / \mathrm{d}$ compared with 95MP. Urinary output of creatinine, a biomarker for muscle mass, and purine derivatives, indicators of microbial CP synthesis, were similar $(P \geq$ 0.31 ) for $109 \mathrm{MP}$ and $95 \mathrm{MP}$. These results support our contention that $\mathrm{N}$ in the 109MP diet was in excess of requirements for the cow and rumen microbes.

When oscillating $\mathrm{CP}$, dietary $\mathrm{N}$ intake was reduced $38 \mathrm{~g} / \mathrm{d}$ compared with $95 \mathrm{MP}$; however, cows fed OSC had similar intakes of digestible $\mathrm{N}$ as 95MP. Greater $\mathrm{N}$ digestibility for OSC did not improve NUE and MP supply compared with $95 \mathrm{MP}$ because milk $\mathrm{N}$ tended to be less and retained $\mathrm{N}$ was numerically less for OSC. Rather, greater $\mathrm{N}$ digestibility led to more $\mathrm{N}$ being excreted in urine. Excretion of purine derivatives was similar between 95MP and OSC. This disagrees with Doranalli et al. (2011) who found oscillating CP in growing lambs decreased urine $\mathrm{N}$ excretion and increased urinary output of purine derivatives. In our study, oscillating CP may have increased urea recycling to the rumen, but less DE intake may have limited the ability of rumen microbes to use the recycled N (Nocek 
and Russell, 1988) and failed to increase NUE when oscillating CP. Retained $\mathrm{N}$ did not differ from zero $(P$ $=0.57)$, which agrees with the body composition data (Table 9), and there was a tendency for greater $(P=$ $0.08)$ creatinine excretion for OSC $(P=0.08)$. These results give further evidence that the catabolism of endogenous $\mathrm{N}$ is probably not the major mechanism causing increased $\mathrm{N}$ excretion.

\section{Body Composition}

Body composition can be predicted accurately with the urea dilution technique (Agnew et al., 2005) and this can be repeated on the same animal. Repeated measurements allow changes in body composition to be calculated. Average estimates of empty body water (mean \pm SD; $62.2 \pm 1.93)$, lipid $(17.1 \pm 2.15)$, protein $(18.1 \pm 0.48)$, and ash $(5.7 \pm 0.32)$ as a percentage of empty BW (Table 9) were similar to slaughter studies in dairy cows (Gibb et al., 1992; Andrew et al., 1994; von Soosten et al., 2012) and to predicted values for cows with a BCS of 3.2 (NRC, 2001).

In our study, feeding different concentrations of $\mathrm{CP}$ or oscillating CP for $50 \mathrm{~d}$ had minimal effects on the final and weekly changes of BCS, BW, empty BW, and empty body components $(P>0.15)$. The weekly change in BW, and empty body lipid and gross en- ergy were greater than zero for all treatments $(P<$ $0.05)$, confirming cows were in positive energy balance. Weekly changes in empty body $\mathrm{CP}$ were not different $(P \geq 0.51)$ from zero for any treatments, indicating these cows did not accrete or lose empty body protein during the 50-d feeding period. Body composition measurements, $\mathrm{N}$ balance data, and plasma 3-methyl-His concentrations indicate that over the 50-d experiment cows fed 95MP or OSC CP were not mobilizing protein stores.

\section{CONCLUSIONS}

Compared with feeding a similar average CP concentration continuously, oscillating the $\mathrm{CP}$ concentrations of a diet $5 \%$ deficient in MP on a 24 -h basis reduced DMI but not milk production. Oscillating CP decreased the proportion of consumed $\mathrm{N}$ that was excreted in feces but increased urinary $\mathrm{N}$, suggesting some other factor, such as reduced intake of $\mathrm{DE}$, was limiting the ability of the cow to convert digested protein into milk. Daily milk and milk protein yields responded to the daily changes in dietary protein, indicating that in mid lactation cows cannot buffer short-term protein deficiencies from body reserves. Concentrations of plasma 3-methyl-His and changes in body protein stores support that suggestion. Future work oscillat-

Table 11. Effects of static or oscillating CP concentrations on $\mathrm{N}$ metabolism and excretion of urine metabolites

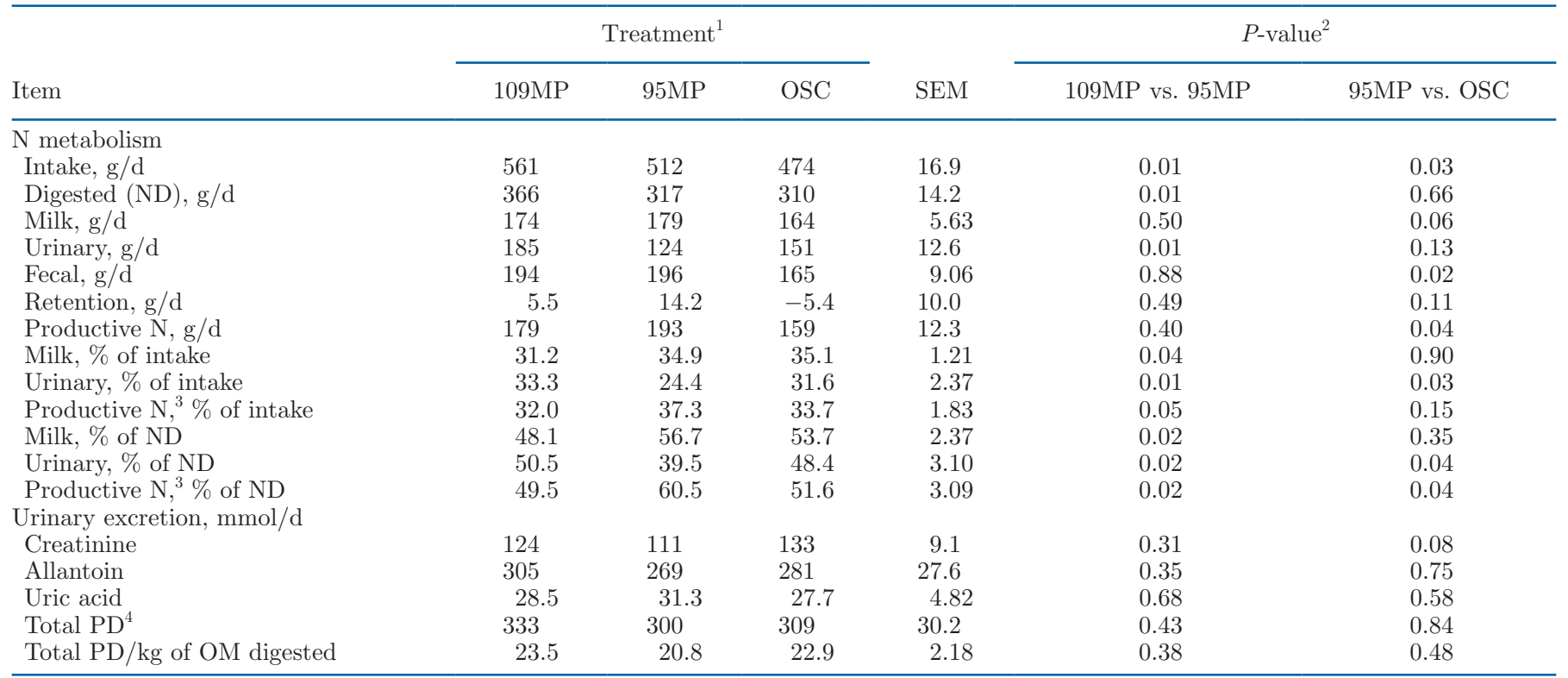

${ }^{1} 109 \mathrm{MP}=$ high phase OSC diet fed continuously; $95 \mathrm{MP}=50: 50 \mathrm{mix}$ of high and low phase OSC diets fed continuously; OSC = oscillating from the high phase OSC diet to low phase OSC diet on a 24-h basis.

${ }^{2} \mathrm{CP}$ concentration: $109 \mathrm{MP}$ vs. $95 \mathrm{MP}$, positive control $(16 \% \mathrm{CP})$ vs. negative $\mathrm{CP}$ control $(14 \% \mathrm{CP})$; oscillation: $95 \mathrm{MP}$ vs. OSC, negative control $(14 \% \mathrm{CP})$ vs. oscillating $\mathrm{CP}(14 \% \mathrm{CP})$.

${ }^{3}$ Productive $\mathrm{N}, \mathrm{g} / \mathrm{d}=$ milk $\mathrm{N}, \mathrm{g} / \mathrm{d}+$ retention, $\mathrm{g} / \mathrm{d}$.

${ }^{4}$ Total purine derivatives $(\mathrm{PD}), \mathrm{mmol} / \mathrm{d}=$ allantoin, $\mathrm{mmol} / \mathrm{d}+$ uric acid, $\mathrm{mmol} / \mathrm{d}$. 
ing $\mathrm{CP}$ to dairy cows should evaluate the type of $\mathrm{CP}$ sources substituted (i.e., ruminal degradability of CP) and what nutrients replace $\mathrm{CP}$ in the deficient $\mathrm{CP}$ diet to minimize negative effects on DMI.

\section{ACKNOWLEDGMENTS}

The authors express appreciation to Donna Wyatt (Ohio State University, Wooster) for laboratory analyses, and to Brent Hostettler and his crew at the Ohio State University Krauss Dairy Center. This project was supported in part by state and federal funds appropriated to the Ohio Agricultural Research and Development Center, Wooster, $\mathrm{OH}$. The authors have not stated any conflicts of interest.

\section{REFERENCES}

Agnew, R., and T. Yan. 2000. Impact of recent research on energy feeding systems for dairy cattle. Livest. Prod. Sci. 66:197-215. https://doi.org/10.1016/S0301-6226(00)00161-5.

Agnew, R., T. Yan, W. McCaughey, J. McEvoy, D. Patterson, M. Porter, and R. Steen. 2005. Relationships between urea dilution measurements and body weight and composition of lactating dairy cows. J. Dairy Sci. 88:2476-2486. https://doi.org/10.3168/jds .S0022-0302(05)72925-8.

Andrew, S. M., D. Waldo, and R. Erdman. 1994. Direct analysis of body composition of dairy cows at three physiological stages. J. Dairy Sci. 77:3022-3033. https://doi.org/10.3168/jds.S0022 -0302(94)77244-1.

AOAC International. 2000. Official Methods of Analysis of the AOAC International. Vol. 1 and 2. AOAC International, Gaithersburg, MD.

Archibeque, S. L., H. Freetly, N. Cole, and C. Ferrell. 2007a. The influence of oscillating dietary protein concentrations on finishing cattle. II. Nutrient retention and ammonia emissions. J. Anim. Sci. 85:1496-1503. https://doi.org/10.2527/jas.2006-208.

Archibeque, S. L., H. Freetly, and C. Ferrell. 2007b. Net portal and hepatic flux of nutrients in growing wethers fed high-concentrate diets with oscillating protein concentrations. J. Anim. Sci. 85:9971005. https://doi.org/10.2527/jas.2006-547.

Bannink, A., H. Valk, and A. Van Vuuren. 1999. Intake and excretion of sodium, potassium, and nitrogen and the effects on urine production by lactating dairy cows. J. Dairy Sci. 82:1008-1018. https: //doi.org/10.3168/jds.S0022-0302(99)75321-X.

Broderick, G. A., and M. K. Clayton. 1997. A statistical evaluation of animal and nutritional factors influencing concentrations of milk urea nitrogen. J. Dairy Sci. 80:2964-2971. https://doi.org/10 .3168/jds.S0022-0302(97)76262-3.

Broderick, G. A., M. Stevenson, R. Patton, N. Lobos, and J. O. Colmenero. 2008. Effect of supplementing rumen-protected methionine on production and nitrogen excretion in lactating dairy cows. J. Dairy Sci. 91:1092-1102. https://doi.org/10.3168/jds.2007-0769.

Brown, A. N. 2014. Effects of oscillating crude protein content of dairy cow diets. MS Thesis. Department of Animal Sciences, The Ohio State University, Columbus.

Chen, X. B. 1989. Excretion of purine derivatives by sheep and cattle and its use for the estimation of absorbed microbial protein. $\mathrm{PhD}$ Diss. University of Aberdeen, Aberdeen, Scotland.

Cole, N. A. 1999. Nitrogen retention by lambs fed oscillating dietary protein concentrations. J. Anim. Sci. 77:215-222. https://doi.org/ 10.2527/1999.771215x.

Cole, N. A., L. Greene, F. McCollum, T. Montgomery, and K. McBride. 2003. Influence of oscillating dietary crude protein concentration on performance, acid-base balance, and nitrogen excretion of steers. J. Anim. Sci. 81:2660-2668. https://doi.org/10.2527/ 2003.81112660x.

De Koster, J. D., and G. Opsomer. 2013. Insulin resistance in dairy cows. Vet. Clin. North Am. Food Anim. Pract. 29:299-322. https: //doi.org/10.1016/j.cvfa.2013.04.002.

Doepel, L., I. Hewage, and H. Lapierre. 2016. Milk protein yield and mammary metabolism are affected by phenylalanine deficiency but not by threonine or tryptophan deficiency. J. Dairy Sci. 99:31443156. https://doi.org/10.3168/jds.2015-10320.

Doranalli, K., G. B. Penner, and T. Mutsvangwa. 2011. Feeding oscillating dietary crude protein concentrations increases nitrogen utilization in growing lambs and this response is partly attributable to increased urea transfer to the rumen. J. Nutr. 141:560-567. https: //doi.org/10.3945/jn.110.133876.

Ellis, J., F. Qiao, and J. Cant. 2006. Evaluation of net energy expenditures of dairy cows according to body weight changes over a full lactation. J. Dairy Sci. 89:1546-1557. https://doi.org/10.3168/jds .S0022-0302(06)72222-6.

Giallongo, F., A. Hristov, J. Oh, T. Frederick, H. Weeks, J. Werner, H. Lapierre, R. Patton, A. Gehman, and C. Parys. 2015. Effects of slow-release urea and rumen-protected methionine and histidine on performance of dairy cows. J. Dairy Sci. 98:3292-3308. https:/ /doi.org/10.3168/jds.2014-8791.

Gibb, M., W. Ivings, M. Dhanoa, and J. Sutton. 1992. Changes in body components of autumn-calving Holstein-Friesian cows over the first 29 weeks of lactation. Anim. Prod. 55:339-360. https:// doi.org/10.1017/S0003356100021036.

Hoffmann, L., and M. Klein. 1980. Die abhängigkeit der harnenergie vom kohlenstoff-und stickstoffgehalt im harn bei rindern, schafen, schweinen und ratten. Arch. Anim. Nutr. 30:743-750. https://doi .org/10.1080/17450398009425086.

Holter, J., and J. T. Reid. 1959. Relationship between the concentrations of crude protein and apparently digestible protein in forages. J. Anim. Sci. 18:1339-1349. https://doi.org/10.2527/jas1959 $.1841339 x$.

Holter, J., and W. Urban Jr.. 1992. Water partitioning and intake prediction in dry and lactating Holstein cows. J. Dairy Sci. 75:14721479. https://doi.org/10.3168/jds.S0022-0302(92)77904-1.

Huhtanen, P., and A. Hristov. 2009. A meta-analysis of the effects of dietary protein concentration and degradability on milk protein yield and milk N efficiency in dairy cows. J. Dairy Sci. 92:32223232. https://doi.org/10.3168/jds.2008-1352.

Ipharraguerre, I., R. Ipharraguerre, and J. Clark. 2002. Performance of lactating dairy cows fed varying amounts of soyhulls as a replacement for corn grain. J. Dairy Sci. 85:2905-2912. https://doi.org/ 10.3168/jds.S0022-0302(02)74378-6.

Isaac, R., and W. Johnson. 1985. Elemental analysis of plant tissue by plasma emission spectroscopy: Collaborative study. J. Assoc. Off. Anal. Chem. 68:499-505. https://doi.org/10.1093/jaoac/68.3.499.

Jones, J., B. Wolf, and H. Mills. 1991. Microwave digestion using CEM microwave digestion system. Plant Analysis Handbook. MicroMacro Publishing, Athens, GA.

Jonker, J., R. Kohn, and R. Erdman. 1998. Using milk urea nitrogen to predict nitrogen excretion and utilization efficiency in lactating dairy cows. J. Dairy Sci. 81:2681-2692. https://doi.org/10.3168/ jds.S0022-0302(98)75825-4.

Jonker, J., R. Kohn, and J. High. 2002. Dairy herd management practices that impact nitrogen utilization efficiency. J. Dairy Sci 85:1218-1226. https://doi.org/10.3168/jds.S0022-0302(02)74185 -4 .

Kiran, D., and T. Mutsvangwa. 2009. Nitrogen utilization in growing lambs fed oscillating dietary protein concentrations. Anim. Feed Sci. Technol. 152:33-41. https://doi.org/10.1016/j.anifeedsci.2009 .03.009.

Lee, C., A. Hristov, T. Cassidy, K. Heyler, H. Lapierre, G. Varga, M. De Veth, R. Patton, and C. Parys. 2012. Rumen-protected lysine, methionine, and histidine increase milk protein yield in dairy cows fed a metabolizable protein-deficient diet. J. Dairy Sci. 95:60426056. https://doi.org/10.3168/jds.2012-5581.

Lee, C., A. N. Hristov, K. Heyler, T. Cassidy, M. Long, B. Corl, and S. Karnati. 2011. Effects of dietary protein concentration and coco- 
nut oil supplementation on nitrogen utilization and production in dairy cows. J. Dairy Sci. 94:5544-5557. https://doi.org/10.3168/ jds.2010-3889.

Ludden, P., T. Wechter, and B. Hess. 2002a. Effects of oscillating dietary protein on nutrient digestibility, nitrogen metabolism, and gastrointestinal organ mass in sheep. J. Anim. Sci. 80:3021-3026. https://doi.org/10.2527/2002.80113021x.

Ludden, P., T. Wechter, and B. Hess. 2002b. Effects of oscillating dietary protein on ruminal fermentation and site and extent of nutrient digestion in sheep. J. Anim. Sci. 80:3336-3346. https:// doi.org $/ 10.2527 / 2002.80123336 x$.

Menezes, A. C. B., S. C. Valadares Filho, M. V. Pacheco, P. Pucetti, B. C. Silva, D. Zanetti, M. F. Paulino, F. F. Silva, T. L. Neville, and J. S. Caton. 2019. Oscillating and static dietary crude protein supply. I. Impacts on intake, digestibility, performance, and nitrogen balance in young Nellore bulls. Transl. Anim. Sci. 3:1205-1215. https://doi.org/10.1093/tas/txz138.

Morris, D., A. Tebbe, W. Weiss, and C. Lee. 2019a. Effects of drying and analytical methods on nitrogen concentrations of feeds, feces, milk, and urine of dairy cows. J. Dairy Sci. 102:5212-5218. https: //doi.org/10.3168/jds.2019-16256.

Morris, D., R. White, and P. Kononoff. 2019b. Prediction of heat production in lactating Jersey cows. Pages 7918-7931 in EAAP Scientific Series. Wageningen Academic Publishers, Wageningen, the Netherlands. https://doi.org/10.3920/978-90-8686-891-9.

Nielsen, N., H. Volden, M. Ảkerlind, M. Brask, A. L. F. Hellwing, T. Storlien, and J. Bertilsson. 2013. A prediction equation for enteric methane emission from dairy cows for use in NORFOR. Acta Agric. Scand. A Anim. Sci. 63:126-130. https://doi.org/10.1080/ 09064702.2013 .851275

Nocek, J., and J. Russell. 1988. Protein and energy as an integrated system. Relationship of ruminal protein and carbohydrate availability to microbial synthesis and milk production. J. Dairy Sci. 71:2070-2107. https://doi.org/10.3168/jds.S0022-0302(88)79782 $-9$.

NRC. 2001. Nutrient Requirements of Dairy Cattle. 7th rev. ed. Natl. Acad. Press, Washington, DC.

Oldham, J. 1984. Protein-energy interrelationships in dairy cows. J. Dairy Sci. 67:1090-1114. https://doi.org/10.3168/jds.S0022 -0302(84)81410-1.

Raggio, G., G. Lobley, R. Berthiaume, D. Pellerin, G. Allard, P. Dubreuil, and H. Lapierre. 2007. Effect of protein supply on hepatic synthesis of plasma and constitutive proteins in lactating dairy cows. J. Dairy Sci. 90:352-359. https://doi.org/10.3168/jds.S0022 -0302(07)72636-X.

Reed, K., H. Bonfa, J. Dijkstra, D. Casper, and E. Kebreab. 2017. Estimating the energetic cost of feeding excess dietary nitrogen to dairy cows. J. Dairy Sci. 100:7116-7126. https://doi.org/10.3168/ jds.2017-12584.

Rietman, A., J. Schwarz, D. Tomé, F. J. Kok, and M. Mensink. 2014. High dietary protein intake, reducing or eliciting insulin resistance? Eur. J. Clin. Nutr. 68:973-979. https://doi.org/10.1038/ ejcn.2014.123.

Tebbe, A., M. Faulkner, and W. Weiss. 2017. Effect of partitioning the nonfiber carbohydrate fraction and neutral detergent fiber method on digestibility of carbohydrates by dairy cows. J. Dairy Sci. 100:6218-6228. https://doi.org/10.3168/jds.2017-12719.

Tebbe, A., D. Wyatt, and W. Weiss. 2018. Effects of magnesium source and monensin on nutrient digestibility and mineral balance in lactating dairy cows. J. Dairy Sci. 101:1152-1163. https://doi .org/10.3168/jds.2017-13782.

Tyrrell, H. F., and J. T. Reid. 1965. Prediction of the energy value of cow's milk. J. Dairy Sci. 48:1215-1223. https://doi.org/10.3168/ jds.S0022-0302(65)88430-2.

VandeHaar, M. J., and N. St-Pierre. 2006. Major advances in nutrition: Relevance to the sustainability of the dairy industry. J. Dairy Sci. 89:1280-1291. https://doi.org/10.3168/jds.S0022 -0302(06)72196-8.

von Soosten, D., U. Meyer, M. Piechotta, G. Flachowsky, and S. Dänicke. 2012. Effect of conjugated linoleic acid supplementation on body composition, body fat mobilization, protein accretion, and energy utilization in early lactation dairy cows. J. Dairy Sci. 95:1222-1239. https://doi.org/10.3168/jds.2011-4548.

Weiss, W., N. St-Pierre, and L. Willett. 2009. Varying type of forage, concentration of metabolizable protein, and source of carbohydrate affects nutrient digestibility and production by dairy cows. J. Dairy Sci. 92:5595-5606. https://doi.org/10.3168/jds.2009-2247.

Weiss, W., and D. Wyatt. 2000. Effect of oil content and kernel processing of corn silage on digestibility and milk production by dairy cows. J. Dairy Sci. 83:351-358. https://doi.org/10.3168/jds.S0022 -0302(00)74886-7.

Weiss, W., and D. Wyatt. 2003. Effect of dietary fat and vitamin E on $\alpha$-tocopherol in milk from dairy cows. J. Dairy Sci. 86:3582-3591. https://doi.org/10.3168/jds.S0022-0302(03)73964-2.

Wu, G. 2009. Amino acids: Metabolism, functions, and nutrition. Amino Acids 37:1-17. https://doi.org/10.1007/s00726-009-0269-0.

\section{ORCIDS}

A. W. Tebbe ำ https://orcid.org/0000-0002-7366-4065

W. P. Weiss @ https://orcid.org/0000-0003-3506-4672 